\title{
Topoisomerase-II-beta Inhibitor Racemic XK469
}

National Cancer Institute

\section{Source}

National Cancer Institute. Topoisomerase-II-beta Inhibitor Racemic XK469. NCI

Thesaurus. Code C2662.

The R-isomer of a synthetic quinoxaline phenoxypropionic acid derivative with proapoptotic and antiproliferative activities. $\mathrm{R}(+)$ XK469 selectively inhibits topoisomerase II-beta, blocks activation of MEK/MAPK signaling kinases, stimulates caspases, and upregulates p53-dependent proteins, including cyclins A and B1, thereby arresting cancer cells in the G2/M phase of the cell cycle. Both $\mathrm{R}(+)$ and $\mathrm{S}(-)$ isomers of this agent are cytotoxic, although the $\mathrm{R}$-isomer is more potent. ( $\mathrm{NCI05)}$ 